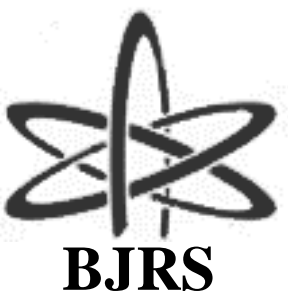

BRAZILIAN JOURNAL

$\mathrm{OF}$

RADIATION SCIENCES

07-03 (2019) 01-10

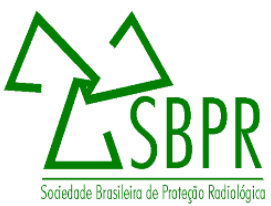

\title{
Fricke Dosimetry as a Tool to Quality Control of Photodynamic Therapy
}

\author{
S. O. Santos ${ }^{\text {a }}$ V. L. B. Souza ${ }^{\mathrm{a}}$ \\ ${ }^{a}$ Divisão de Análises Ambientais/Serviço de Análises Ambientais, Centro Regional de Ciências Nucleares/Comissão \\ Nacional de Energia Nuclear, 50740525, Recife-PE, Brazil \\ vivilu.bormann@gmail.com
}

\section{RESUMO}

A terapia fotodinâmica (PDT) consiste na associação de um agente fotossensibilizador com uma fonte de luz causando necrose celular. Azul de metileno, azul de toluidina e verde de malaquite são fotossensibilizantes derivados de corantes que são amplamente aceitos na medicina, pois apresentam baixa toxicidade e são de baixo custo. PDT é um tratamento alternativo para o câncer, com vantagens significativas em relação a procedimentos como cirurgia/quimioterapia. Nosso laboratório estudou a solução Fricke dopada com fotosensibilizadores para obter um controle da qualidade para PDT. A solução Fricke foi preparada com sulfato ferroso amoniacal, cloreto de sódio e ácido sulfúrico em água. As soluções modificadas com fotosensibilizantes foram preparadas com adição de 0,1 g/100 mL dos corantes. Um volume de 2,6 ml da solução Fricke modificada com fotossensibilizadores foi transferido para tubos de ensaio e irradiado. As soluções irradiadas tiveram suas densidades ópticas medidas em um espectrofotômetro. As amostras foram irradiadas com LED (Light Emitting Diodes) em simuladores de acrílico. As amostras FATA irradiadas com LED mostraram a sensibilidade dos dosímetros à luz vermelha, azul, verde e amarela. Obteve-se uma curva de calibração com coeficiente de correlação de 0.9884 para a luz vermelha; 0,9752 para luz azul; 0,9644 para a luz verde e 0,9768 para a luz amarela. O fato de que há uma sensibilidade dos dosímetros ao LED indica que a PDT pode ser realizada com LED com menores custos do que com laser. Este trabalho sugeriu que os dosímetros FATA podem ser usados para o controle da qualidade de PDT. 
Palavras-chave: dosimetria, câncer de pele, tratamento.

\begin{abstract}
Photodynamic therapy (PDT) consists of the association of a photosensitizing agent with a light source in order to cause cellular necrosis. Methylene blue, toluidine blue and malachite green are photosensitizers derived from dyes that are widely accepted in medicine, as they have low toxicity and are low cost. PDT is an alternative treatment for cancer, with significant advantages over procedures such as surgery/chemotherapy. Our laboratory has studied the Fricke solution doped with photosensitizers in an approach to obtain a quality control for PDT. The Fricke solution was prepared with ammoniacal ferrous sulfate, sodium chloride and sulfuric acid in water. The solutions modified with photosensitizers were prepared by adding $0.1 \mathrm{~g} / 100 \mathrm{~mL}$ of the dyes. A volume of $2.6 \mathrm{ml}$ of the Fricke solution modified with photosensitizers were transferred to test tubes and irradiated. The irradiated solutions had their optical densities measured in a spectrophotometer. The samples were irradiated with LED (Light Emitting Diodes) in acrylic phantoms. The FATA samples irradiated with LED showed the sensitivity of the dosimeters to red, blue, green and yellow light. A calibration curve with correlation coefficient of 0.9884 for the red light was obtained; 0.9752 for blue light; 0.9644 for the green light and 0.9768 for the yellow light. The fact that a sensitivity of the dosimeters to the LED has been occurred indicates that the PDT could be realized with LED, with lower costs than with laser. This work suggested that FATA dosimeters can be used for quality control of PDT.
\end{abstract}

Keywords: dosimetry, skin cancer, treatment.

\title{
1. INTRODUCTION
}

The Fricke dosimeter modified with dyes using for dosimetry has been a tool in quality control in photodynamic therapy. Photodynamic Therapy is applied for the treatment of some types of skin cancer as well as bone, breast and lung cancer, because dyes are characterized by their ability to absorb visible light being safety and effectiveness [1]. Due to the fact of absorbing light with high efficiency, some of these compounds are able to induce or participate in photochemical reactions [2]. Photodynamic Therapy assumes that the interaction of adequate wavelength light with a photosensitizer (dye) and oxygen result in reactive species capable of inducing the invigi- 
lation of cancer cells. This is a result of the reaction involved, which results from the electronic excitation of the dye by light.

A tumor is characterized by an abnormal growth of living tissue, which can be benign or malignant. The three classic treatments adopted against cancer are chemotherapy, radiotherapy and surgery (removal of damaged tissue and its surroundings), which have numerous disadvantages, such as: disfigurement of the patient, damage to their self-esteem, numerous side effects chemotherapy and radiotherapy, as well as a perspective of healing that is not always effective. As a result, alternative treatments have been developed, including Photodynamic Therapy [3].

There are currently lasers covering the entire visible and near infrared spectrum, thus being able to attend many of the existing phototherapeutic agents in the market. Such lasers are capable of delivering pulsed light of considerable power with precision on the fabric to be irradiated. The use of light emitting diodes (LEDs) has also become viable, allowing a greater reduction in the cost of the procedures.

The laboratory of Chemical Dosimetry of the Regional Center of Nuclear Sciences has worked with some dyes, as possible photosensitizing agents and that can be used in phototherapy and radiotherapeutic treatments, among them: methylene blue, malachite green and currently being tested blue Toluidine. The laboratory has also verified that the addition of ethanol can improve the action of the dyes in dosimetric solution, which corroborates with the results presented by other authors regarding the solubility of the dyes and the stability of the dosimetric solution. As well as the concomitant use of radiotherapy and photodynamic therapy in patients with cancer.

According to Brennan (2006) [4], there is a correlation between the emitted frequency and the color of the light emitted and that reaches the man (Table 1) and certain regions which are more sensitive to certain colors like: hypogastro - orange; Spleen - yellow; Heart - green; Throat blue; Eye - violet; Head - white or violet. 
Table 1: Correlations between color and frequency

\begin{tabular}{l|l}
\hline Color & Frequency Hz $($ cycles/s) \\
\hline Blue & $250-275$ e 1200 \\
\hline Green & $250-475$ \\
\hline Yellow & $500-700$ \\
\hline Orange & $950-1050$ \\
\hline Red & $1000-1200$ \\
\hline Violet & $1000-2000$ e $300-400$ e $600-800$ \\
\hline White & $1100-2000$ \\
\hline
\end{tabular}

The colors harmonize with the normal physiological processes of the body in order to provide a vehicle for psychosomatic functioning. It is suggested red to cure cancer, yellow for better functioning of the organ, green as restorative, blue as soothing and eliminates pain, reaching deep tissues and bone cells [4]. In this work, yellow and green LED emitting at 620 - $630 \mathrm{~nm}$ were used, in previous laboratory work, red and blue LED were used. The aim of this work was to evaluate the effect of light-emitting diodes on Fricke solution modified with dyes.

\section{METHODS}

A $500 \mathrm{~mL}$ volumetric flask without a cap was weighed on a semi-analytical scale with precision of two decimal places; the flask was filled with ultra-pure water to approximately $250 \mathrm{~mL}$ and 11 $\mathrm{mL}$ of sulfuric acid PA (H2SO4) was added slowly; the flask containing the sulfuric acid solution was pre-irradiated with a dose of $10 \mathrm{~Gy}$ using X-ray equipment. $0.196 \mathrm{~g}$ of ferrous ammonium sulfate hexahydrate, $0.030 \mathrm{~g}$ of sodium chloride, and the weighed amounts were transferred into the $500 \mathrm{ml}$ flask by adjusting the weight of the flask with ultra pure water.

To each $100 \mathrm{~mL}$ of this solution was added $0.01 \mathrm{~g}$ of toluidine blue dye (sufficient amount to a concentration of $100 \mu \mathrm{g} / \mathrm{mL}$ dye), made in triplicate. Subsequently, ethanol (with the aim of 
improving the stability and sensitivity of the solutions) [5] was added to the dosimeters giving rise to dosimeter. A volume of $2.6 \mathrm{~mL}$ (Fig. 1) of the dosimeters (the Fricke solution - which simulates blood plasma - modified with the addition of dies and ethanol - FATA (Fricke + toluidine blue + alcohol)) was transferred to test tubes were irradiated with a 19 commercially available LEDs (Light emitting diodes) emitting: red, blue, green light and yellow light at 620 - 630 $\mathrm{nm}$ (Fig. 2) for $120 \mathrm{~h}$, in test tubes located on the surface of acrylic simulators $110 \mathrm{~mm} \times 110$ $\mathrm{mm} \times 80 \mathrm{~mm}$, perpendicular to the central axis of the radiation beam at a distance of $6.5 \mathrm{~cm}$ from the light source.

The samples were read in a Beckman DU-640 spectrophotometer (fig. 3), at wavelength $304 \mathrm{~nm}$ (suitable value for irradiated Fricke dosimeter). The average values below $5 \%$ of error are considered valid. Standard samples of known optical densities $(D=1,5$ and $\quad D=0.3$ ) were read in parallel.

Figure 1: Fricke dosimeters' preparation modified with

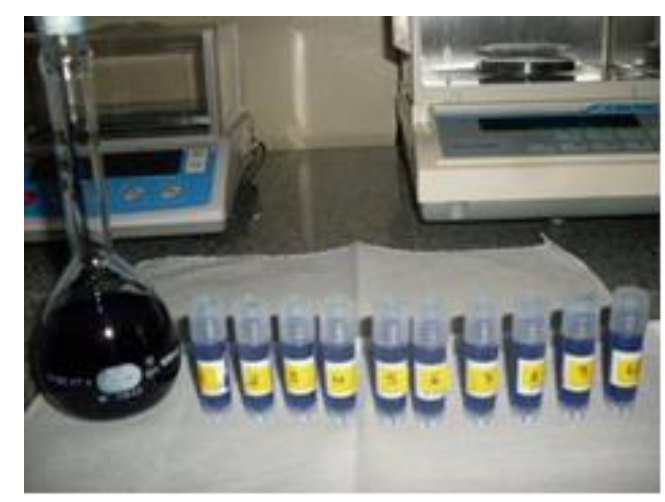

Figure 2: Irradiation Experiments

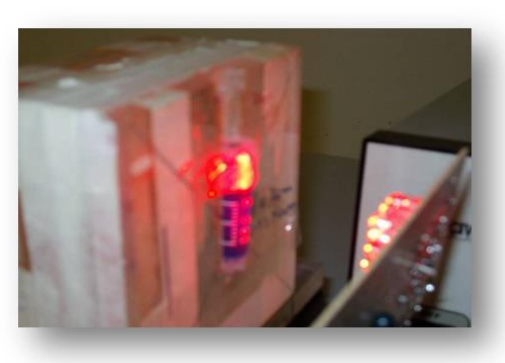

(a)

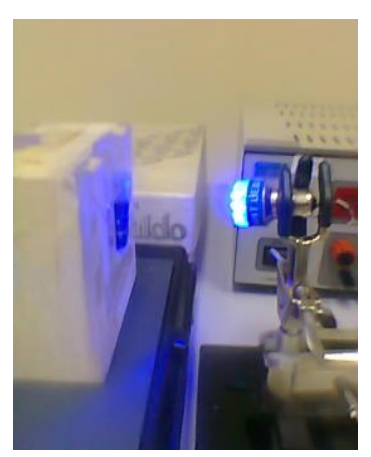

(b)

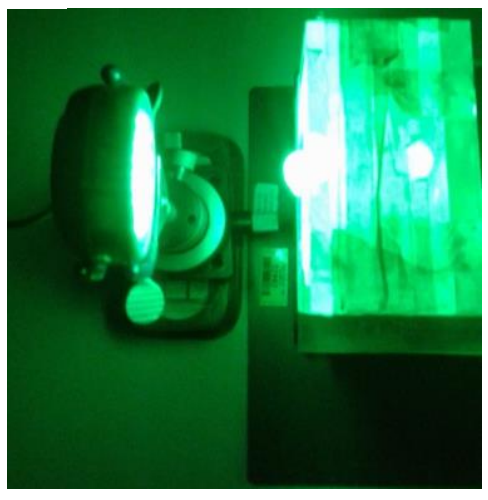

(c) 


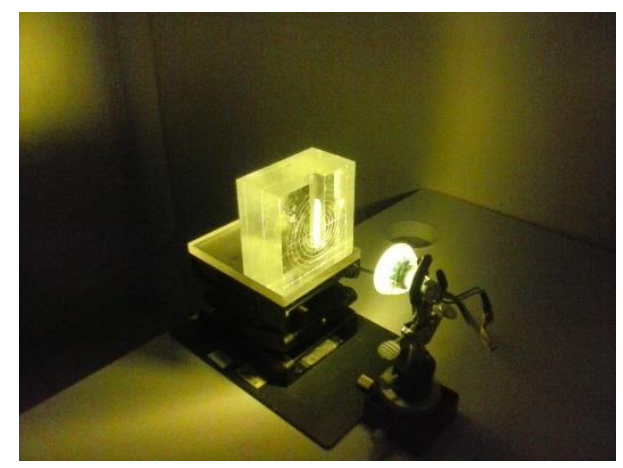

(d)

Figure 3: Beckman DU 640 Spectrophotometer

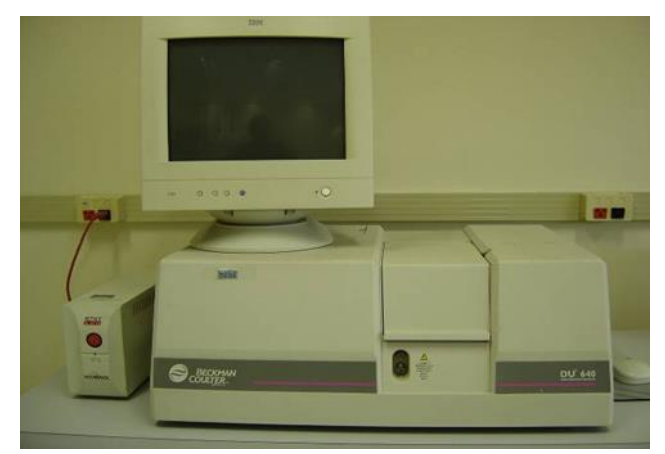

\section{RESULTS AND DISCUSSIONS}

In this study we verified that the addition of ethanol did not increase the sensitivity of the dosimeter as suggested by Podgorsak [5]. Nevertheless, for some photosensitizers, the stability of the solution was enhanced.

An ideal dosimeter should present some characteristics such as linearity of response (for instance, an increase in the optical density with a proportional increase in the irradiation time) and should not suffer the influence of environmental conditions (such as ambient light and temperature). The results obtained for the linearity of the responses are shown in Figures 4-7. These Figures show the linearity of the dosimeter's behavior, demonstrating proportionality between its response (i. e., the increase in Optical Density) and the increase in the irradiation time. 
The results obtained for the FAT irradiated with LED emitting red light show a linear relationship between the increase in Optical Density and the increase in the irradiation time, with a correlation coefficient of 0.9884 . For samples irradiated with green and blue LEDs, on the other hand, correlation coefficients of the regression lines were 0.9644 and 0.9783 , respectively. And the result for correlation coefficient when the dosimeter was irradiated with yellow light was 0.9290 .

Figure 4: Optical Density as a function of duration of irradiation with red LED for FATA.

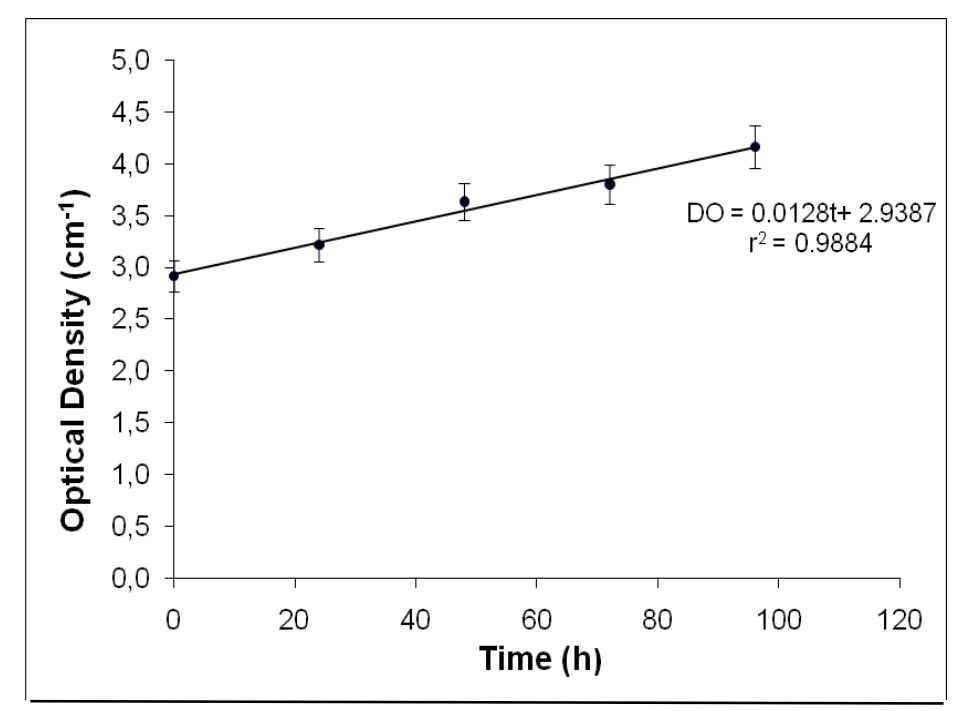

Figure 5: Optical Density as a function of duration of irradiation with green LED for FATA. 


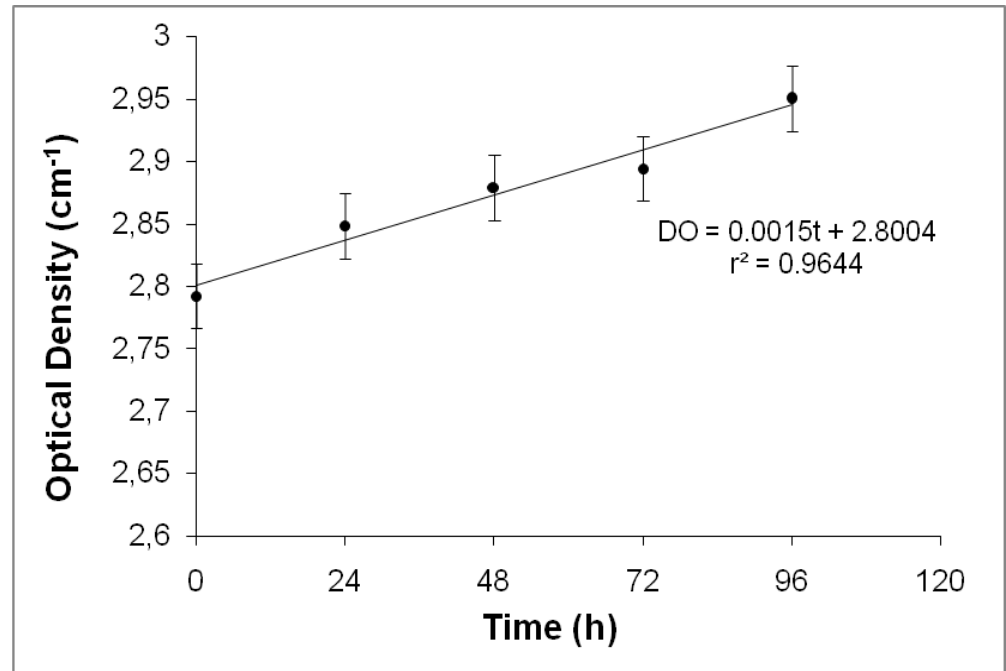

Figure 6: Optical Density as a function of duration of irradiation with blue LED for FATA.

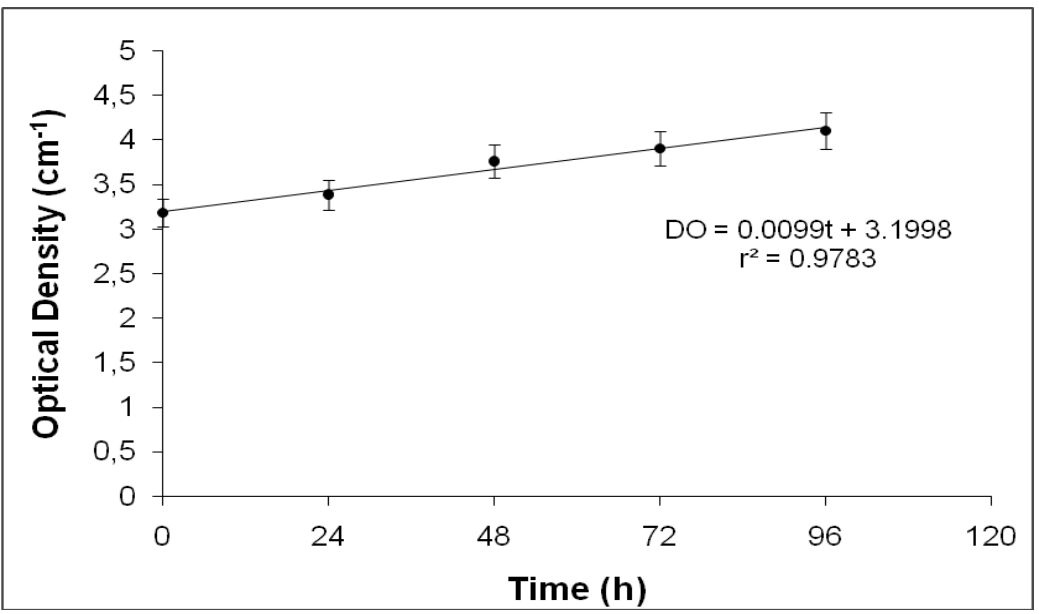


Figure 7: Optical Density as a function of duration of irradiation with yellow LED for FATA.

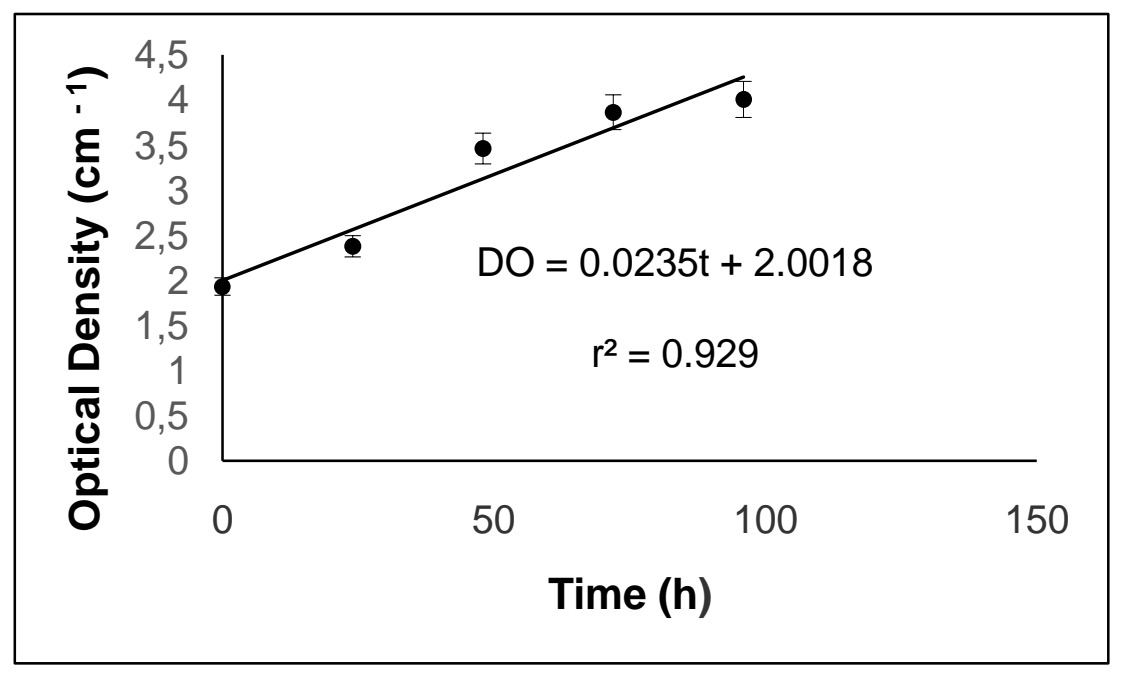

\section{CONCLUSION}

Samples irradiated with LED showed sensitivity to red, green, blue and yellow lights, demonstrating that PDT can be performed with LED obtained a lower cost when compared to the use of lasers. Furthermore, the results show that it is more appropriate to irradiate the FATA dosimeter with the red light than with the blue, green and yellow lights. The results obtained show calibration curves with fairly good correlation coefficients, suggesting that FATA can be applied to perform quality control in photodynamic therapy.

\section{KNOWLEGMENT}

CNPq (Conselho Nacional de Desenvolvimento Científico e Tecnológico)/CNEN (Comissão Nacional de Energia Nuclear) and Waldecy Ananias da Silva. 


\section{REFERENCES}

1. ZOLlinger, H. Color Chemistry - Syntheses, Properties and Applications of Organic Dyes and Pigments, $2^{\text {nd }} e d .$, VCG Publishers. Weinheim. 1991.

2. NSEYO, U. O. Long-term results of whole bladder wall photodynamic therapy for carcinoma in situ of the bladder. Urologic Clinics of North America - Journal, v. 19, p. 591. 1992.

3. LIMA, A.; GASETTA, D.; GRACETTO, A; HIOKA, N.; MAGINI, M. R. R.; OLIVEIRA, H. P. M. Propriedades Espectroscópicas de Corantes com Potencial Uso em Terapia Fotodinâmica em Solução. In: X ENCONTRO LATINO AMERICANO DE INICIAÇÃO CIENTÍFICA 2006, São José dos Campos, São Paulo. Annals... Universidade do Vale do Paraíba, 2006. p. 94 $-97$.

4. BRENNAN, B. A. Mãos de Luz. $21^{\text {st }}$ ed., Pensamento, São Paulo. 2006.

5. PODGORSAK, M. B. 1989. Fricke radiation dosimetry using nuclear magnetic resonance, Tese de Mestrado em Física, Departamento de Física da Universidade McGill, Montreal. 1989. 